\title{
Validation of an Inductively Coupled Plasma Optical Emission Spectrometry Method for the Determination of 18 Elements in the Five Sections of Abutilon theophrasti Medic. (Velvetleaf)
}

\author{
Chunlian Tian ${ }^{\mathrm{a}}$, Miao Wanga, Yongcai $\mathrm{Li}^{\mathrm{b}}$, Xiaokun Liu ${ }^{\mathrm{a}}$, and Chunjie Zhao ${ }^{\mathrm{a}}$ * \\ ${ }^{a}$ Department of Pharmaceutical Analysis, School of Pharmacy, Shenyang Pharmaceutical University, \\ No. 103 Wenhua Road Shenhe Dist. 110016, Shenyang Liaoning Prov., P.R. China \\ b Animal Feed Quality and Safety of Veterinary Testing Centers, \\ No. 281 Xiaonan Street Shenhe Dist. 110016, Shenyang Liaoning Prov., P.R. China
}

\section{INTRODUTION}

Elements are found widely in the environment and, depending on their concentration, play an important role in the prevention of cardiovascular diseases, endemic diseases, cancer, and aging, or lead to disequilibrium and metabolic disorder, causing some diseases.

Traditional Chinese medicines (TCMs) are very complex and contain many organic compounds and inorganic elements (macro or micro elements). Therefore, besides the organic compounds, the inorganic constituents cannot be ignored when studying the therapeutic effects of TCMs. The quality and use of traditional Chinese medicines with regard to their inorganic components can be evaluated by determining the elements present in the samples. This is important since $\mathrm{Cu}, \mathrm{Fe}$, or $\mathrm{Mn}$ can increase the rate of oxidation in an organism, while $\mathrm{V}, \mathrm{Ni}$, As, $\mathrm{Cd}$, and $\mathrm{Pb}$ play an important metabolic role but, depending on concentration, can become toxic. Micro elements are functional components of enzymes, hormones, vitamins, and nucleic acids. The levels of the micro elements will influence the metabolism, the endocrine system, and isohydric conditions in the body.

*Corresponding autbor.

E-mail: zcjiljj@sina.com

Tel: $+86-24-23986299$

Fax: +86-24-23986250

\section{ABSTRACT}

An inductively coupled plasma optical emission spectrometry (ICP-OES) method was developed for the speedy and simultaneous determination of 18 elements (Li, $\mathrm{Na}, \mathrm{Mg}, \mathrm{K}, \mathrm{Ca}$, $\mathrm{V}, \mathrm{Cr}, \mathrm{Mn}, \mathrm{Fe}, \mathrm{Co}, \mathrm{Ni}, \mathrm{Cu}, \mathrm{Zn}, \mathrm{As}$, $\mathrm{Mo}, \mathrm{Cd}, \mathrm{Ba}$, and $\mathrm{Pb}$ ) in five sections (roots, stems, leaves, seeds, and exocarps) of Abutilon theophrasti Medic. (velvetleaf).

The proposed method showed good linearity between the peak area of each analyte and its concentration $(r \geq 0.9991)$. The relative standard deviation (RSD) of the instrumental precision was less than $2.9 \%$. The recoveries were within the 82.7-100.2\% range, with an RSD from $0.36-7.6 \%$. The LODs and LOQs were $0.0002-0.0197 \mu \mathrm{gL}^{-1}$ $(\mathrm{S} / \mathrm{N}=3)$ and 0.0009-0.0422 $\mu \mathrm{g}$ $\mathrm{mL}^{-1}(\mathrm{~S} / \mathrm{N}=10)$, respectively. The results indicate that ICP-OES is an alternative method for use in the determination of macro elements ( $\mathrm{Na}, \mathrm{Mg}, \mathrm{K}, \mathrm{Ca})$, micro elements (Cr, $\mathrm{Mn}, \mathrm{Fe}, \mathrm{Co}, \mathrm{Cu}$, $\mathrm{Zn}, \mathrm{Mo})$, toxic elements ( $\mathrm{V}, \mathrm{Ni}$, As, $\mathrm{Cd}, \mathrm{Pb}$ ), and other elements of interest (Li, Ba) in Abutilon theophrasti Medic., and for quality control of crude drugs and their products. The established method was successfully applied to the multi-elemental determinations of complex traditional Chinese medicines.
\end{abstract}

The quantification of elements in TCMs is particularly difficult to perform because some are present at very low concentrations, and sample preparation is a critical step in the analytical procedure. J.O. Olowoyo et al. (1) digested plants with $10 \mathrm{~mL}$ of nitric acid $\left(\mathrm{HNO}_{3}\right)$ and $3 \mathrm{~mL}$ of perchloric acid $\left(\mathrm{HClO}_{4}\right)$. Aziz A. Fallah et al. (2) mixed the samples with $8 \mathrm{~mL}$ of $68 \% \mathrm{HNO}_{3}$ and $4 \mathrm{~mL}$ of $30 \%$ hydrogen peroxide $\left(\mathrm{H}_{2} \mathrm{O}_{2}\right)$ in a Teflon ${ }^{\circledR}$ beaker. Comparison studies of the dry, wet, and microwave digestion methods for the multi-element determination in some dried fruit samples by ICP-OES were reported by Huseyin Altundag et al. (3). Juliana Naozuka et al. (4) used 65\% (w/v) $\mathrm{HNO}_{3}$ and $30 \%$ (w/v) $\mathrm{H}_{2} \mathrm{O}_{2}$ for sample digestion. In summary, it is a routine and common procedure to employ nitric acid in a mixture of hydrogen peroxide or perchloric acid for the decomposition of complex matrices.

The traditional methods of hydride generation atomic absorption spectrometry (HG-AAS) $(5,6)$, flame atomic absorption spectrometry (FAAS) (7-9), and graphite furnace atomic absorption spectrometry (GF-AAS) $(10,11)$ are simple, versatile, and specific for the determination of macro elements. However, for the quantitative determination of micro elements, inductively coupled plasma optical emission spectrometry (ICP-OES) (12-16), or inductively coupled plasma mass spectrometry (ICP-MS) (17-20), have become employed. 
These latter techniques are also used for the determination of multielements in the environment, foods, plants, and TCMs, and provide higher selectivity and sensitivity for assaying micro elements and isotopic composition. ICP-OES is used in a wide range of applications with relatively low cost and simple sample preparation.

The use of Abutilon theophrasti Medic. (velvetleaf) is widespread in China, except in the Tibetan Plateau, and is cultivated in northeastern China, Vietnam, India, Japan, Europe, and North America. The plant has multiple pharmacological properties (21-22) and is effective for flatulence, detoxification, and inflammation, as well as treating rheumatic pain, arthralgia, bruises, sprains, dysentery, otitis media, tinnitus, and deafness.

However, most of the previously reported studies on the assay of Abutilon theophrasti Medic. are focused on the organic chemical components. To our knowledge, little is known about the qualitative and quantitative research on the elemental composition of Abutilon theophrasti Medic.

In this study, a mixed acid digestion procedure coupled with ICPOES was developed for the simple and rapid determination of 18 elements found in the roots, stems, leaves, seeds, and exocarps of $\mathrm{Abu}$ tilon theophrasti Medic. The optimized method developed is a useful tool for quality control of TCMs.

\section{EXPERIMENTAL}

\section{Instrumentation}

A Model Optima ${ }^{\mathrm{TM}}$ 2000DV inductively coupled plasma optical emission spectrometer (PerkinElmer, Inc. Shelton, CT, USA) was used for this study, including a DB-3 temperature-controlled hot plate (Jiangsu Jintan Jincheng GuoSheng Co., P.R. China), SZ-97 automatic triple pure water distiller (Shanghai Yarong Co., P.R. China), BSA124S electronic balance (Sartorius, Ltd., Germany), and a disintegrator (Jiangyin Yongchang Machine Co. Ltd., P.R. China). The instrumental and operating conditions are listed in Table I, and the analytical lines of the elements are listed in Table II.

TABLE I

ICP-OES Instrumental and Operating parameters for the Determination 18 Elements

\begin{tabular}{|c|c|}
\hline Instrument & Optima 2000DV ICP-OES \\
\hline Operational Software & WinLab $^{\text {TM }} 32$ \\
\hline Analytical Lines & Axial \\
\hline Viewing Height & $15 \mathrm{~mm}$ \\
\hline Nebulizer Type & Concentric Glass \\
\hline Spray Chamber Type & Baffled Cyclonic \\
\hline Tubing Type & Standard PVC \\
\hline Tubing i.d. & $3.18 \mathrm{~mm}$ \\
\hline RF Power & $1300 \mathrm{~W}$ \\
\hline Nebulizer Flow & $0.8 \mathrm{~L} \mathrm{~min}^{-1}$ \\
\hline Plasma Gas Flow & $14 \mathrm{~L} \mathrm{~min}^{-1}$ \\
\hline Auxiliary Gas Flow & $0.2 \mathrm{~L} \mathrm{~min}^{-1}$ \\
\hline Sample Aspiration Rate & $1.4 \mathrm{mLmin}^{-1}$ \\
\hline Argon Purity & $99.99 \%$ \\
\hline Sample Pump Rate & $25 \mathrm{rpm}$ \\
\hline
\end{tabular}

WinLab $^{\text {TM }} 32$

Axial

$15 \mathrm{~mm}$

Concentric Glass

Baffled Cyclonic

Standard PVC

$3.18 \mathrm{~mm}$

$1300 \mathrm{~W}$

$0.8 \mathrm{~L} \mathrm{~min}^{-1}$

$14 \mathrm{~L} \mathrm{~min}^{-1}$

$0.2 \mathrm{~L} \mathrm{~min}^{-1}$

$99.99 \%$

$25 \mathrm{rpm}$

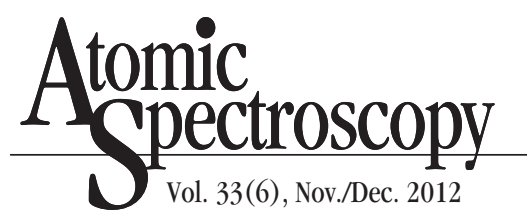

All glass- and plasticware was immersed in $20 \%$ (v/v) nitric acid solution for a mininum of 12 hours, then washed with triple distilled deionized water and air-dried.

\section{Standard Solutions and Reagents}

The stock standard solutions (1000 $\mathrm{gmmL}^{-1}$ elemental concentration) were prepared from the following certified samples:

$\mathrm{Li}$ (GBW (E) 080547), Na (GBW (E) 080552), Mg (GBW (E) 080554), $\mathrm{K}$ (GBW (E) 080553), Ca (GBW (E) 080555), Fe (GBW (E) 080624), Cu (GSB 05-1117-2000), Cd (GBW (E) 080608), Ba (GBW (E) 080589) (National Research Center for Standard Material, P.R. China).

V (GSBG62016-90), Mn (GSBG62019-90), Co (GSBG6202190), Ni (GSBG62022-90), As (GSBG62028-90), Mo (GSBG6203590), $\mathrm{Pb}$ (GSBG62071-90) (National Analysis Center for Iron and Steel, P.R. China).

Cr (GSB 07-1284-2000) and Zn (GSB 07-1283-2000) from Standard Sample Research Institute of State Environmental Protection Administration, P.R. China.

All of the elements were viewed axially.

The reagents were of analytical guaranteed grade and included the following: Nitric acid (Beijing Yili

TABLE II Axial Analytical Lines of 18 Elements by ICP-OES

\begin{tabular}{cccc}
\hline Elements & $\lambda(\mathrm{nm})$ & Elements & $\lambda(\mathrm{nm})$ \\
\hline $\mathrm{Li}$ & 670.784 & $\mathrm{Co}$ & 238.892 \\
$\mathrm{Na}$ & 588.995 & $\mathrm{Ni}$ & 221.648 \\
$\mathrm{Mg}$ & 285.213 & $\mathrm{Cu}$ & 324.752 \\
$\mathrm{~K}$ & 766.490 & $\mathrm{Zn}$ & 206.200 \\
$\mathrm{Ca}$ & 317.933 & $\mathrm{As}$ & 193.696 \\
$\mathrm{~V}$ & 292.464 & $\mathrm{Mo}$ & 202.031 \\
$\mathrm{Cr}$ & 267.716 & $\mathrm{Cd}$ & 214.440 \\
$\mathrm{Mn}$ & 257.610 & $\mathrm{Ba}$ & 455.403 \\
$\mathrm{Fe}$ & 259.939 & $\mathrm{~Pb}$ & 220.356
\end{tabular}


Fine Chemicals Co., Ltd., Beijing, P.R. China), perchloric acid (Tianjin Xinyuan Chemical Co., Ltd., Tianjin, P.R. China), and hydrogen peroxide (Tianjin Oubokai Chemical Co., Ltd., Tianjin, P.R. China).

\section{Sample Preparation}

The five sections (roots, stems, leaves, seeds, and exocarps) of Abutilon theophrasti Medic. were collected from the Jilin province in China (No.101124, harvesting time) and authenticated by Professor Jingming Jia of Shenyang Pharmaceutical University.

Approximately $1 \mathrm{~g}$ of each sample (roots, stems, leaves, seeds, and exocarps), was rinsed with $50 \mathrm{~mL}$ of triple distilled deionized water to remove the salts and soil, ovendried at $100 \pm 5^{\circ} \mathrm{C}(23)$, then crushed and ground to fine powder (crushed with a disintegrator). A 0.5-g portion of each sample was accurately weighed and introduced into wide-mouth conical glass flasks. An amount of $10 \mathrm{~mL}$ of mixed acid $\left(8 \mathrm{~mL} \mathrm{HNO}_{3}+2 \mathrm{~mL}\right.$ $\left.\mathrm{HClO}_{4}, 4: 1, \mathrm{v} / \mathrm{v}\right)$ was carefully added to each sample, the flasks were gently shaken and allowed to sit overnight at room temperature. The second day, the samples were digested for one hour at $150{ }^{\circ} \mathrm{C}$ on a hot plate, and then for two hours at $250^{\circ} \mathrm{C}$ on a hot plate where the color of the fumes turned from brown to white. After the white fumes disappeared (the sample solution became achromatous and transparent or yellowish), two aliquots of $5 \mathrm{~mL}$ of triple distilled deionized water was added to the nitrate solution, and the sample solution digested sequentially at $300{ }^{\circ} \mathrm{C}$ until the volume of the residual solution was 1-2 mL. Finally, the digested solution was cooled and transferred to $10 \mathrm{~mL}$ volumetric flasks, diluted with $1 \%$ nitric acid, then analyzed by ICPOES. A sampler peristaltic pump was adopted as sample introduc- tion system for use in the ICP-OES system. The sample aspiration rate was $1.4 \mathrm{~mL} \mathrm{~min}^{-1}$ at a sample pump rate of $25 \mathrm{rpm}$.

Blanks, consisting of triple distilled deionized water and the oxidant mixture, were treated the same as for the sample preparation and the analytical procedures.

\section{Method Verification}

\section{Calibration Curves}

Stock solutions (for each of the 18 reference elements) were prepared and diluted to appropriate concentrations for construction of the calibration curves. Each concentration of the mixed standard solution was injected into the ICPOES. The calibration curves were constructed by plotting the peak area versus the concentration of each element. The concentration range for each element is listed in Table III.

\section{Limits of Detection (LOD) and Quantification (LOQ)}

Sensitivity was evaluated by determining the LOD and LOQ. The stock solutions of the 18 reference elements were diluted to a series of appropriate concentrations, and an aliquot of each of the diluted solutions was determined by ICP-OES. The limits of detection (LOD) and quantification (LOQ) were determined at a signal-to-noise ratio $(\mathrm{S} / \mathrm{N})$ of about 3 and 10 , respectively.

\section{Precision, Repeatability, and Accuracy}

For verification of instrument precision, the mixed standard solutions were analyzed for six replicates within the same day.

Variations were expressed by calculating the relative standard deviation (RSD). To confirm repeatability, six replicates of the same samples were extracted and analyzed as mentioned above. The RSD value was calculated as a measurement of method repeatability.
Spike recovery was used to evaluate the accuracy of the method. A known amount of standard was added to a certain amount of each element to the sample. The mixture was extracted and analyzed using the method mentioned above. Three replicates were used to perform the tests.

\section{Statistical Analysis}

One-way ANOVA, performed by SPSS (v.13.0) software for the Microsoft ${ }^{\circledR}$ Windows ${ }^{\circledR}$ operating system (SPSS Inc., Chicago, IL, USA), was used to estimate the overall significance. A probability level of $5 \%(p \leq 0.05)$ was considered significant.

\section{RESULTS AND DISCUSSION}

\section{Screening of the Digestion System}

To release 18 elements efficiently from the complex matrices, the reagent selection, hot plate heating process, and heating time for the digestion, which are closely connected with extraction and release capacities of the elements, were investigated. The composition and ratio of the digestion solvents, such as $\mathrm{HNO}_{3}: \mathrm{HClO}_{4}(10: 1,5: 1$, $4: 1,2: 1, \mathrm{v} / \mathrm{v})$ and $\mathrm{HNO}_{3}: \mathrm{H}_{2} \mathrm{O}_{2}$ (10:1, 5:1, 4:1, 2:1, v/v), were screened and investigated. It was found that the organic constituents of the samples were decomposed more rapidly and completely using $\mathrm{HNO}_{3}: \mathrm{HClO}_{4}(4: 1$, v/v) when heating on a hot plate was adopted for sample pre-treatment.

\section{Optimization of Plasma Operat- ing Conditions and Selection of Analytical Lines}

The ICP-OES operating parameters (axial view) were set as recommended by the manufacturer with some minor changes. The specific parameters used for routine analysis are listed in Table I.

The emission lines of the analytes were selected on the basis of 
their net and background intensities and their freedom from spectral interference overlaps. Multielement standard solutions of the investigated matrices and the different certified reference material solutions after digestion were scanned by ICP-OES over the selected wavelength range to monitor the line interferences.

\section{Method Validation}

Calibration, $L O D$, and $\angle O Q$

The calibration graphs corresponding to the 18 elements (Li, Na, Mg, K, Ca, V, Cr, Mn, Fe, $\mathrm{Co}, \mathrm{Ni}, \mathrm{Cu}, \mathrm{Zn}$, As, Mo, Cd, Ba, and $\mathrm{Pb})$ show good linearity function response, as indicated by the $r \geq 0.9991$ value (determination coeffcient). The LOD of the 18 elements varied from 0.0002 to $0.0197 \mu \mathrm{g} \mathrm{mL}^{-1}$, and the LOQ ranged from 0.0009 to $0.0422 \mu \mathrm{g} \mathrm{mL}^{-1}$ (see Table III).
Precision, Repeatability, and Accuracy

The RSD values corresponding to the instrumental precision (as listed in Table III) were less than $1.1 \%$ and $2.9 \%$, respectively. The reproducibility of the quantification of the 18 elements, expressed as the RSD, was less than $2.9 \%$. The results of recovery for accuracy are listed in Table IV. The overall recoveries ranged from 82.7 $100.2 \%$, with the RSD ranging from $0.36 \%$ to $7.6 \%$. The results indicated that the methodology tests were in accordance with the test requirements.

Elemental Composition of Samples

The method proposed was validated for the simultaneous determination of 18 elements found in the roots, stems, leaves, seeds, and exocarps of Abutilon theophrasti

\section{A Spmic $_{\text {vol } 33(6) \text {. Nov Dec . 2012 }}^{\text {tome }}$}

Medic. The mean concentrations of the elements in the samples are listed in Table V. The distributions of macro, micro, toxic, and other elements in the five plant parts are listed in Figures 1, 2, 3, and 4, respectively. This study showed that the concentrations of the elements in the five sections of $\mathrm{Abu}$ tilon theophrasti Medic. were in different concentrations. The results also showed that high levels of the macro elements $\mathrm{Na}, \mathrm{Mg}, \mathrm{K}$, and $\mathrm{Ca}$ were found in these five sections. Also found were heavy or toxic elements $(\mathrm{V}, \mathrm{Ni}, \mathrm{As}, \mathrm{Cd}$, and $\mathrm{Pb}$ ), which do not have a metabolic function but can become harmful to humans even at low concentrations. However, the concentrations of toxic elements found in the examined samples were lower than the legislated limits.

\section{TABLE III}

Calibration, LOD, LOQ, Precision, and Repeatability of 18 Elements

\begin{tabular}{|c|c|c|c|c|c|c|c|}
\hline \multirow[t]{2}{*}{ Elements } & \multirow{2}{*}{$\begin{array}{l}\text { Calibration } \\
\text { Curves }\end{array}$} & \multirow{2}{*}{$\begin{array}{l}\text { Correlation } \\
\text { Coefficient (r) }\end{array}$} & \multirow{2}{*}{$\begin{array}{l}\text { Linear } \\
\text { Range } \\
\left(\mu \mathrm{g} \mathrm{mL}^{-1}\right)\end{array}$} & \multirow{2}{*}{$\begin{array}{c}\text { LOD } \\
\left(\mu \mathrm{g} \mathrm{mL}^{-1}\right)\end{array}$} & \multirow{2}{*}{$\begin{array}{l}\text { LOQ } \\
\left(\mu \mathrm{g} \mathrm{mL} L^{-1}\right)\end{array}$} & \multicolumn{2}{|c|}{ Precision Repeatability } \\
\hline & & & & & & (\%) & $(\%)$ \\
\hline $\mathrm{Li}$ & $A=6.500 \times 105 C+5.490 \times 103$ & 0.9995 & $0.001-2.0$ & 0.0003 & 0.0011 & 2.7 & 2.9 \\
\hline $\mathrm{Na}$ & $\mathrm{A}=3.128 \times 105 \mathrm{C}+9.435 \times 104$ & 1.0 & $0.05-100.0$ & 0.0197 & 0.0418 & 1.7 & 1.7 \\
\hline $\mathrm{Mg}$ & $A=3.219 \times 104 C+1.616 \times 104$ & 0.9994 & $0.05-100.0$ & 0.0088 & 0.0354 & 1.8 & 1.9 \\
\hline K & $A=1.738 \times 104 C+5.780 \times 103$ & 0.9992 & $0.05-100.0$ & 0.0175 & 0.0326 & 1.8 & 2.0 \\
\hline $\mathrm{Ca}$ & $A=3.077 \times 104 C+3.346 \times 104$ & 0.9998 & $0.05-100.0$ & 0.0033 & 0.0108 & 1.5 & 1.8 \\
\hline V & $A=5.452 \times 103 C+1.028 \times 102$ & 1.0 & $0.01-20.0$ & 0.0026 & 0.0082 & 1.7 & 2.5 \\
\hline $\mathrm{Cr}$ & $A=2.030 \times 104 C-1.161 \times 102$ & 0.9997 & $0.01-20.0$ & 0.0011 & 0.0064 & 2.3 & 2.4 \\
\hline $\mathrm{Mn}$ & $A=1.048 \times 105 C+1.338 \times 104$ & 0.9995 & $0.01-20.0$ & 0.0019 & 0.0086 & 2.9 & 2.4 \\
\hline $\mathrm{Fe}$ & $A=2.324 \times 104 C+1.358 \times 104$ & 0.9995 & $0.05-100.0$ & 0.0062 & 0.0282 & 2.6 & 2.7 \\
\hline $\mathrm{Co}$ & $A=7.859 \times 103 C+4.61 \times 10$ & 0.9998 & $0.001-2.0$ & 0.0003 & 0.0010 & 1.6 & 1.6 \\
\hline $\mathrm{Ni}$ & $A=2.472 \times 10 C+2.443 \times 102$ & 0.9991 & $0.01-20.0$ & 0.0039 & 0.0091 & 2.5 & 2.6 \\
\hline $\mathrm{Cu}$ & $A=6.899 \times 104 C+1.105 \times 104$ & 0.9996 & $0.01-20.0$ & 0.0023 & 0.0078 & 1.5 & 1.8 \\
\hline $\mathrm{Zn}$ & $A=8.368 \times 102 C+4.970 \times 10$ & 0.9998 & $0.05-100.0$ & 0.0091 & 0.0422 & 1.9 & 1.3 \\
\hline As & $\mathrm{A}=1.062 \times 102 \mathrm{C}-2.017$ & 0.9992 & $0.001-2.0$ & 0.0003 & 0.0013 & 1.4 & 2.7 \\
\hline Mo & $A=5.759 \times 102 C+1.022 \times 102$ & 0.9993 & $0.01-20.0$ & 0.0031 & 0.0096 & 1.5 & 1.7 \\
\hline $\mathrm{Cd}$ & $\mathrm{A}=3.870 \times 104 \mathrm{C}+7.42 \times 10$ & 0.9998 & $0.001-2.0$ & 0.0002 & 0.0010 & 1.8 & 2.0 \\
\hline $\mathrm{Ba}$ & $A=2.662 \times 106 C+2.351 \times 105$ & 0.9999 & $0.05-100.0$ & 0.0114 & 0.0375 & 1.1 & 1.4 \\
\hline $\mathrm{Pb}$ & $A=8.344 \times 102 C+1.398 \times 10$ & 0.9993 & $0.001-2.0$ & 0.0002 & 0.0009 & 2.0 & 1.8 \\
\hline
\end{tabular}


TABLE IV

Recovery of the 18 Elements

\begin{tabular}{|c|c|c|c|c|c|c|c|c|c|}
\hline Elements & $\begin{array}{l}\text { Low conc. } \\
\left(\mu \mathrm{g} \mathrm{mL}^{-1}\right)\end{array}$ & $\begin{array}{c}\text { Recovery } \\
(\%)\end{array}$ & $\begin{array}{l}\text { RSD } \\
(\%)\end{array}$ & $\begin{array}{l}\text { Middle conc. } \\
\left(\mu \mathrm{g} \mathrm{mL} \mathrm{mL}^{-1}\right)\end{array}$ & $\begin{array}{c}\text { Recovery } \\
(\%)\end{array}$ & $\begin{array}{l}\text { RSD } \\
(\%)\end{array}$ & $\begin{array}{l}\text { High conc. } \\
\left(\mu \mathrm{g} \mathrm{mL} \mathrm{mL}^{-1}\right)\end{array}$ & $\begin{array}{c}\text { Recovery } \\
(\%)\end{array}$ & $\begin{array}{r}\text { RSD } \\
(\%)\end{array}$ \\
\hline $\mathrm{Li}$ & 0.01 & 86.2 & 1.5 & 0.2 & 87.3 & 2.4 & 2.0 & 99.2 & 0.78 \\
\hline $\mathrm{Na}$ & 0.5 & 91.5 & 4.2 & 10.0 & 90.2 & 3.8 & 100.0 & 94.4 & 1.7 \\
\hline $\mathrm{Mg}$ & 0.5 & 88.7 & 2.2 & 10.0 & 91.4 & 1.7 & 100.0 & 93.4 & 3.8 \\
\hline K & 0.5 & 83.6 & 5.3 & 10.0 & 90.8 & 2.0 & 100.0 & 93.2 & 4.2 \\
\hline $\mathrm{Ca}$ & 0.5 & 84.8 & 2.6 & 10.0 & 92.3 & 1.8 & 100.0 & 94.8 & 3.5 \\
\hline V & 0.1 & 86.7 & 1.3 & 2.0 & 88.2 & 1.6 & 20.0 & 96.4 & 0.72 \\
\hline $\mathrm{Cr}$ & 0.1 & 87.4 & 4.8 & 2.0 & 88.2 & 0.36 & 20.0 & 91.2 & 1.5 \\
\hline $\mathrm{Mn}$ & 0.1 & 86.1 & 2.8 & 2.0 & 87.7 & 0.97 & 20.0 & 96.3 & 1.6 \\
\hline $\mathrm{Fe}$ & 0.5 & 88.6 & 7.6 & 10.0 & 89.2 & 6.2 & 100.0 & 100.2 & 2.2 \\
\hline $\mathrm{Co}$ & 0.01 & 82.7 & 3.2 & 0.2 & 84.6 & 3.1 & 2.0 & 89.7 & 2.1 \\
\hline $\mathrm{Ni}$ & 0.1 & 89.2 & 5.7 & 2.0 & 92.3 & 2.3 & 20.0 & 95.5 & 3.0 \\
\hline $\mathrm{Cu}$ & 0.1 & 84.9 & 4.7 & 2.0 & 86.2 & 1.9 & 20.0 & 93.1 & 1.8 \\
\hline $\mathrm{Zn}$ & 0.5 & 83.4 & 3.3 & 10.0 & 85.4 & 1.1 & 100.0 & 97.4 & 0.73 \\
\hline As & 0.01 & 84.2 & 2.6 & 0.2 & 94.0 & 2.5 & 2.0 & 94.7 & 0.92 \\
\hline Mo & 0.1 & 91.4 & 5.4 & 2.0 & 93.3 & 1.5 & 20.0 & 89.6 & 0.74 \\
\hline $\mathrm{Cd}$ & 0.01 & 90.5 & 6.2 & 0.2 & 92.4 & 7.9 & 2.0 & 98.3 & 1.9 \\
\hline $\mathrm{Ba}$ & 0.5 & 89.4 & 0.72 & 10.0 & 90.4 & 4.3 & 100.0 & 94.4 & 1.7 \\
\hline $\mathrm{Pb}$ & 0.01 & 86.3 & 4.4 & 0.2 & 85.5 & 6.4 & 2.0 & 87.6 & 1.9 \\
\hline
\end{tabular}

TABLE V

Concentration of the 18 Elements in the Real Samples $(n=3)$

\begin{tabular}{|c|c|c|c|c|c|}
\hline Elements & $\begin{array}{l}\text { Roots } \\
\left(\mu \mathrm{g} \mathrm{mL}^{-1}\right)\end{array}$ & $\begin{array}{l}\text { Stems } \\
\left(\mu \mathrm{g} \mathrm{mL} L^{-1}\right)\end{array}$ & $\begin{array}{l}\text { Leaves } \\
\left(\mu \mathrm{g} \mathrm{mL}^{-1}\right)\end{array}$ & $\begin{array}{c}\text { Seeds } \\
\left(\mu \mathrm{g} \mathrm{mL}^{-1}\right)\end{array}$ & $\begin{array}{l}\text { Exocarps } \\
\left.(\mu \mathrm{g} \mathrm{mL})^{-1}\right)\end{array}$ \\
\hline $\mathrm{Li}$ & $0.17 \pm 0.01^{\mathrm{a}}$ & $0.21 \pm 0.01$ & b & - & $0.027 \pm 0.002$ \\
\hline $\mathrm{Na}$ & $54.2 \pm 2.8$ & $21.9 \pm 1.5$ & $3.02 \pm 0.23$ & $5.46 \pm 0.10$ & $7.71 \pm 0.09$ \\
\hline Mg & $87.3 \pm 9.7$ & $428 \pm 13$ & $329 \pm 26$ & $241 \pm 22$ & $162 \pm 4$ \\
\hline $\mathrm{K}$ & $417 \pm 7$ & $1943 \pm 36$ & $927 \pm 32$ & $742 \pm 14$ & $975 \pm 9$ \\
\hline $\mathrm{Ca}$ & $1861 \pm 93$ & $1777 \pm 92$ & $1468 \pm 94$ & $1073 \pm 61$ & $1779 \pm 27$ \\
\hline $\mathrm{V}$ & - & $0.40 \pm 0.02$ & $0.30 \pm 0.02$ & $0.26 \pm 0.01$ & - \\
\hline $\mathrm{Cr}$ & $2.37 \pm 0.33$ & $3.60 \pm 0.24$ & $0.52 \pm 0.05$ & $80 \pm 3$ & $0.38 \pm 0.02$ \\
\hline Mn & $0.55 \pm 0.03$ & $7.56 \pm 0.28$ & $16.6 \pm 1.4$ & - & $2.3 \pm 0.2$ \\
\hline $\mathrm{Fe}$ & $11.8 \pm 1.3$ & $301 \pm 12$ & - & - & - \\
\hline Co & - & $0.031 \pm 0.002$ & $0.06 \pm 0.01$ & - & - \\
\hline $\mathrm{Ni}$ & - & $0.83 \pm 0.05$ & - & $0.21 \pm 0.01$ & - \\
\hline $\mathrm{Cu}$ & - & $3.25 \pm 0.22$ & - & - & $0.37 \pm 0.01$ \\
\hline $\mathrm{Zn}$ & $3.41 \pm 0.16$ & $1.5 \pm 0.3$ & - & - & $2.41 \pm 0.09$ \\
\hline As & - & $0.28 \pm 0.01$ & $0.037 \pm 0.003$ & - & - \\
\hline Mo & - & - & $2.2 \pm 0.4$ & - & - \\
\hline $\mathrm{Cd}$ & - & $0.047 \pm 0.004$ & - & - & - \\
\hline $\mathrm{Ba}$ & $1240 \pm 29$ & $2.45 \pm 0.41$ & $1640 \pm 99$ & $4.97 \pm 0.17$ & $2.78 \pm 0.09$ \\
\hline $\mathrm{Pb}$ & - & $0.44 \pm 0.06$ & $0.07 \pm 0.01$ & - & - \\
\hline
\end{tabular}

a. Results are presented as means and standard deviations obtained from three replicated analysis.

b Not detected. 


\section{Atomic Apectroscopy \\ $\bigcup$ Vol. 33(6), Nov./Dec. 2012}

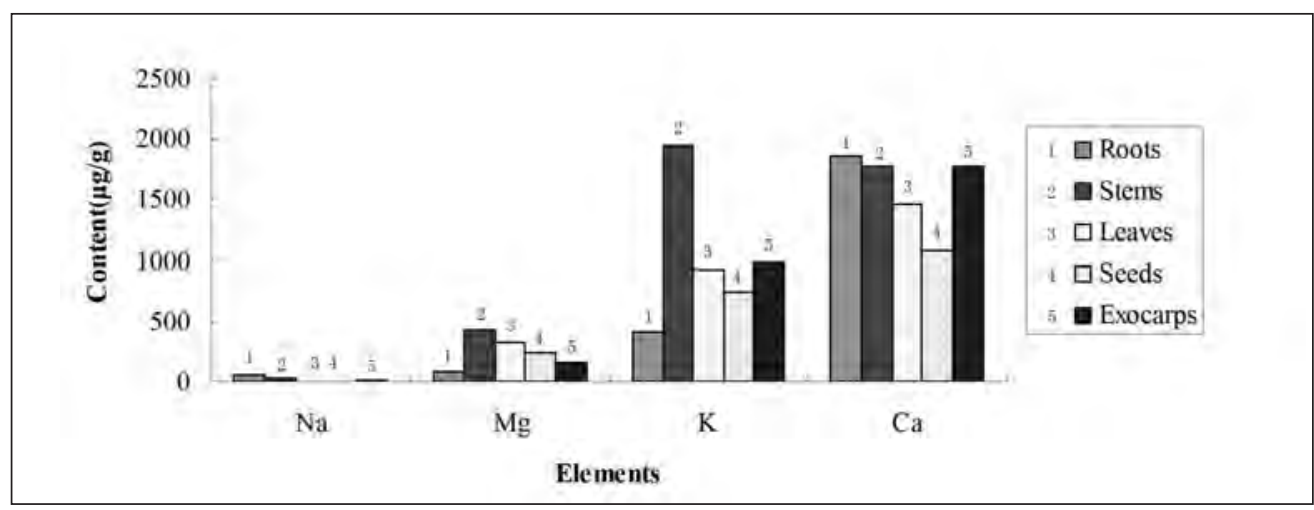

Fig. 1. Distribution of Macro Elements in the Five Sections of Abutilon theopbrasti Medic.

Fig. 2. Distribution of Micro Elements in the Five Sections of Abutilon theophrasti Medic.
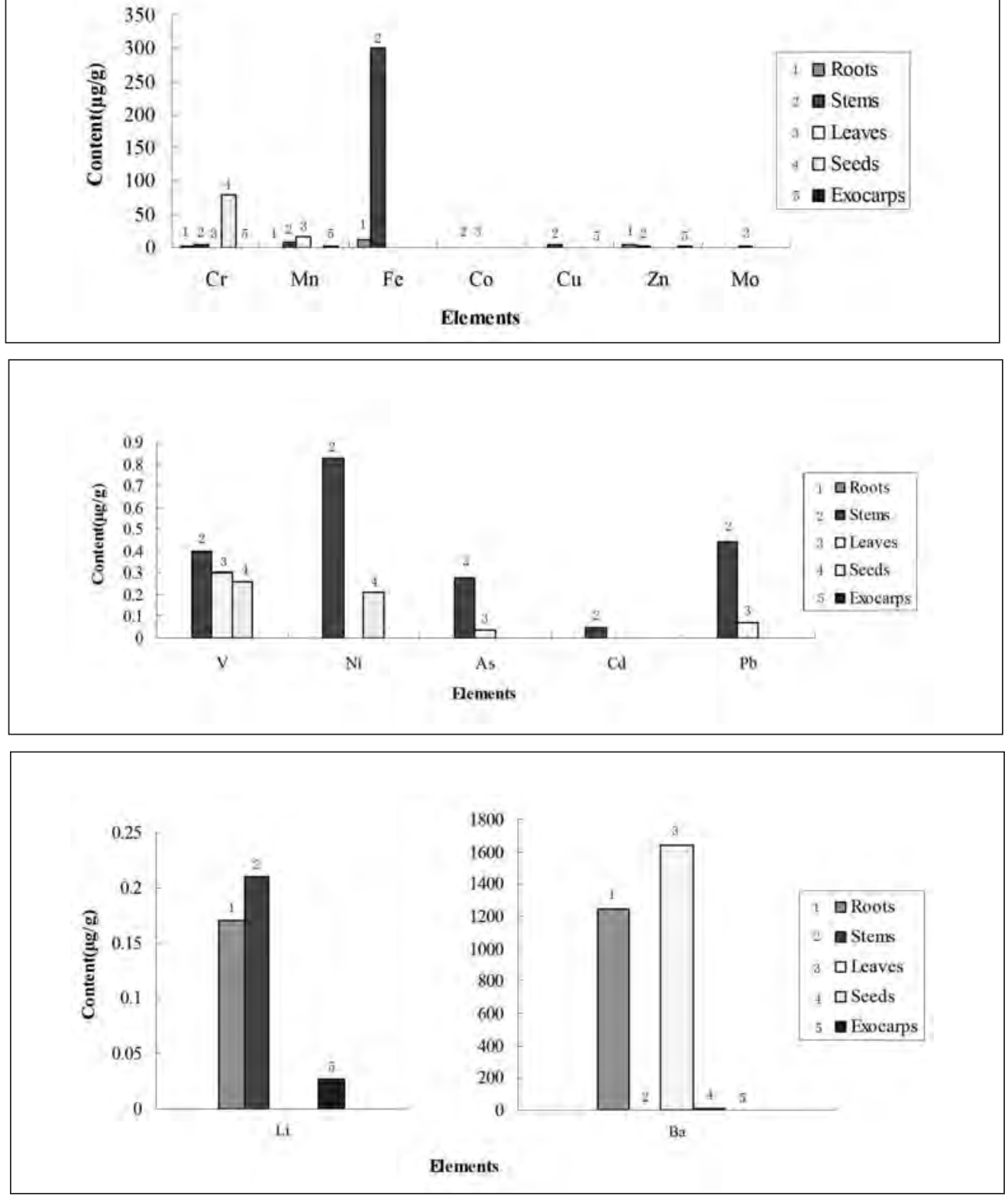

Fig. 3. Distribution of Toxic Elements in the Five Sections of Abutilon theophrast $i$ Medic.

Fig. 4. Distribution of Other Elements in the Five Sections of Abutilon theophrasti Medic. 


\section{CONCLUSION}

In this work, a simple, robust, and reliable inductively coupled plasma optical emission spectrometry (ICP-OES) method was developed for the simultaneous determination of macro and micro elements in the roots, stems, leaves, seeds, and exocarps of Abutilon theophrasti Medic. (velvetleaf).This plant is widely used in China for rheumatic pain, slight incontinence, otitis, and other diseases. The sample digestion conditions, such as composition and ratio of digestion solvents, the analytical lines and instrumental parameters, were carefully optimized covering a large spectral range (193.696$766.490 \mathrm{~nm}$ ).

The three levels of spike recoveries at different spiking levels provide guarantee for the accuracy of the method from low concentrations to high concentrations. As a result of matrix interference and the low concentration of the elements, the lower recoveries were obtained at lower spiking levels, but the overall recoveries were more than 82.7 , which had no effect on the accuracy of the method and usability of data. The developed method was successfully applied to the qualitative and quantitative assay of the elements in traditional Chinese medicines (TCMs).

The method can be used to provide technical support for quality appraisal, pharmacological and clinical research. Excellent limits of detection were obtained for the macro elements ( $\mathrm{Na}, \mathrm{Mg}, \mathrm{K}, \mathrm{Ca}$ ), the micro elements $(\mathrm{Cr}, \mathrm{Mn}, \mathrm{Fe}, \mathrm{Co}$, $\mathrm{Cu}, \mathrm{Zn}, \mathrm{Mo})$, the toxic elements ( , $\mathrm{Ni}, \mathrm{As}, \mathrm{Cd}, \mathrm{Pb}$ ), and other elements (Li, Ba). The procedural parameters of the method were found suitable for the purpose of elemental analysis. The toxicity of small amounts of As, $\mathrm{Cd}$, and $\mathrm{Pb}$ released into TCMs is generally known. Other micro elements may have a similar effects when present in higher concentrations.

The results presented in this paper show that the level of $\mathrm{K}$ and $\mathrm{Ca}$ was higher than $\mathrm{Na}$ and $\mathrm{Mg}$ in the five sections; micro elements $\mathrm{Cr}, \mathrm{Mn}, \mathrm{Fe}$ were comparatively high; toxic elements were detected primarily from the stems and leaves, which enlarge the knowledge of the elemental composition in Abutilon theophrasti Medic. The roots, seeds, and exocarps which are more effective for particular treatments are much less toxic. The concentration of toxic elements in the other sections were all lower than the international limits. Since the toxic elements can been removed, this will be useful knowledge in the toxicological and therapeutical fields.

Received June 26, 2012.

\section{REFERENCES}

1. J.O. Olowoyo, O.O., Okedeyi, N.M. Mkolo, G.N. Lion, S.T.R. Mdakane South African J. of Botany 78, 116 (2012).

2. A.A. Fallah, S.S. Saei-Dehkordi, A. Nematollahi, and T. Jafari, Microchem. J. 98, 275 (2011).

3. H. Altundag and M. Tuzen, Food and Chem. Toxico. 49, 2800 (2011).

4. J. Naozuka, E.C. Vieira, A.N. Nascimento, P.V. Oliveira, Food Chem. 124, 1667 (2011).

5. O. Hegedűs, A. Hegedűsová, S. Šimková, V. Pavlík, K. Jomová, J. Biochem. and Biophy. Methods 70, 1287 (2008).

6. A.A. Shaltout, I.N.B. Castilho, B Welz, E. Carasek, I.B.G. Martens, A. Martens, S.M.F. Cozzolino, Talanta, 85, 1350 (2011).

7. E.J. Llorent-Martínez, P. Ortega-Barrales, M.L. Fernández-de Córdova, A. Domínguez-Vidal, A. RuizMedina, Food Chem. 127, 1257 (2011).
8. V.P. Stankov Jovanovic, M.D. Ilic, M.S. Markovic, V.D. Mitic, S.D. Nikolic Mandic, G.S. Stojanovic, Chemosphere 84, 1584 (2011).

9. M.A.B. Gonzalo, R. Jasan, R. Plá, M.L. Pignata, J. of Haz. Mat. 193, 264 (2011).

10. S. Scaccia and R. Mecozzi, Microchem. Journal 100, 48 (2011).

11. N.L. Bjorklund, V.M. Sadagoparamanujam, G. Taglialatela, J. of Neuros. Methods 203, 146 (2012).

12. C.S. Larrañaga and I.N. Blasco, Food Chem. 115, 1048 (2009).

13. J.S. Jallath, A.C. Rodríguez, J.H. Casillas, L.T. Bustillos, Physics and Chem. of the Earth, 37-39, 10 (2012).

14. R.A. Sousa, N. Baccan, S. Cadore, Food Chem. 124, 1264 (2011).

15. M.H. Karbasi, B. Jahanparast, M. Shamsipur, J. Hassan, J. of Haz. Materials 170, 151 (2009).

16. J.S. Suleiman, B. Hu, C.Z. Huang, N. Zhang, J. of Haz. Materials 157,410 (2008).

17. N. Luy, S. Gobert, S. Sartoretto, R. Biondo, J.M. Bouquegneau, J. Richir, Ecological Indicators 18, 269 (2012).

18. T.A. Coudron, L.C. Mitchell, R. Sun, J.D. Robertson, N.V. Pham, H.J.R Popham, Biol. Control, doi: 10.1016/ j.biocontrol.2012.01.011.

19. C. Vique, P.R. Carmen Bouzas, I. López, J. María. Food Chem.2012, doi: $10.1016 /$ j.foodchem. 2012.02.088.

20. M. Malavolta, F. Piacenza, A. Basso, R. Giacconi, L. Costarelli, S. Pierpaoli, Anal. Biochem. 421, 16 (2012).

21. C.D. Fu and Y.F. Hong, Y.F., Forens. Med. Sci. 15, 4 (1993).

22. G.Y, Gu and Y. Jiang, Mod. Pharm. Cli. 24, 338 (2009).

23. M.T. Larrea-Marín, M.S. PomaresAlfonso, M. Gómez-Juaristi, F.J. Sánchez-Muniz, S. Ródenas de la Rocha, J. of Food Composition and Analysis, 23, 814 (2010). 